\title{
Possible Mechanisms of Cardiac Contractile Dysfunction and Electrical Changes in Ammonium Chloride Induced Chronic Metabolic Acidosis in Wistar Rats
}

\author{
N. N. LASHEEN ${ }^{1}$, G. F. MOHAMED ${ }^{2}$ \\ ${ }^{1}$ Department of Physiology, Faculty of Medicine, Ain Shams University, Cairo, Egypt, ${ }^{2}$ Department \\ of Histology, Faculty of Medicine, Ain Shams University, Cairo, Egypt
}

Received August 28, 2015

Accepted May 20, 2016

On-line August 19, 2016

\begin{abstract}
Summary
Metabolic acidosis could occur due to either endogenous acids accumulation or bicarbonate loss from the gastrointestinal tract or commonly from the kidney. This study aimed to investigate the possible underlying mechanism(s) of chronic acidosis-induced cardiac contractile and electrical changes in rats. Twenty four adult Wistar rats, of both sexes, were randomly divided into control group and chronic metabolic acidosis group, which received orally $0.28 \mathrm{M} \mathrm{NH}_{4} \mathrm{Cl}$ in the drinking water for 2 weeks. At the end of experimental period, systolic and diastolic blood pressure values were measured. On the day of sacrifice, rats were anesthetized by i.p. pentobarbitone $(40 \mathrm{mg} / \mathrm{kg}$ b.w.), transthoracic echocardiography and ECG were performed. Blood samples were obtained from abdominal aorta for complete blood count and determination of $\mathrm{pH}$, bicarbonate, chloride, sodium, potassium, troponin I, CK-MB, IL-6, renin and aldosterone levels. Hearts from both groups were studied for cardiac tissue IL- 6 and aldosterone in addition to histopathological examination. Compared to control group, chronic metabolic acidosis group showed anemia, significant systolic and diastolic hypotension accompanied by significant reduction of ejection fraction and fraction of shortening, significant bradycardia, prolonged QTC interval and higher widened $\mathrm{T}$ wave as well as significantly elevated plasma levels of renin, aldosterone, troponin I, CK-MB and IL-6, and cardiac tissue aldosterone and IL-6. The left ventricular wall of the acidosis group showed degenerated myocytes with fibrosis and apoptosis. Thus, chronic metabolic acidosis induced negative inotropic and chronotropic effects and cardiomyopathy, possibly by elevated aldosterone and IL-6 levels released from the cardiac tissue.
\end{abstract}

\section{Key words}

Aldosterone • Cardiac • Chronic metabolic acidosis • ECG • IL-6

\section{Corresponding author}

N. N. Lasheen, Department of Physiology, Faculty of Medicine, Ain Shams University, Ramsis St. Abbasseya, Cairo, Egypt. E-mail: nohalasheen@med.asu.edu.eg, nlashen@yahoo.com

\section{Introduction}

Metabolic acidosis, a common clinical condition, is caused by a decrease in blood $\mathrm{pH}$ and bicarbonate concentration (Wagner 2007). It could occur acutely, lasting for a few hours to a day, or as a chronic condition when normal $\mathrm{pH}$ could not be fully restored. Metabolic acidosis also could occur frequently as a secondary complication, and have detrimental effect on patients' outcome with various life-threatening conditions (Weiner and Hamm 2007). It was observed that metabolic acidosis could result from many conditions such as chronic kidney diseases (Kraut and Kurtz 2005), lactic acidosis (Lorenz 2009), diabetic ketoacidosis (Kraut and Madias 2012) and diet induced acidosis (Yancy et al. 2007).

Acidosis, as a dominant type of acid base disturbance, has been reported to cause complex dysregulation of cardiovascular functions (Curley et al. 2010). Allen and Orchard (1983) reported that acidosis could induce a negative inotropic effect in the heart, through alteration of electrical activity, pumps and channels, and modifications of myofilament sensitivity to calcium (Crampin and Smith 2006). Also, Biais et al. 
(2012) reported that metabolic acidosis could impair the positive inotropic effect of $\beta$-adrenergic stimulation. However, Schotola et al. (2002) found insignificant inotropic effect of mild metabolic acidosis on isometrically contracting muscle strips from non-failing sheep hearts.

Also, Perez et al. (1979) found that metabolic acidosis induced by $\mathrm{HCl}$ or $\mathrm{NH}_{4} \mathrm{Cl}$ was associated with increased aldosterone production without concomitant changes in plasma renin activity. In a later study, Henger et al. (2000) suggested that inhibition of aldosterone action by spironolactone in chronic metabolic acidosis resulted in exacerbated acidosis by a non-renal mechanism possibly mediated by glucocorticoids rise. Mihailidou (2012) reported that sustained aldosterone rise could induce cardiovascular damage independently from renal sodium regulation and blood pressure effects.

Therefore, it was observed that studies on the cardiac effects of acidosis have been performed mostly in isolated tissues or myocytes, and the $\mathrm{pH}$ values used were rather low ( $\sim 6.0$ to 6.5$)$, corresponding to local acidosis in cardiac tissue during ischemia. The alterations of cardiac function in vivo, also depend on other factors such as changes in venous return, afterload, autonomic nervous system, and compensatory mechanisms (Biais et al. 2012). However, few researches dealing with the effect of chronic metabolic acidosis on contractile function of the heart in vivo are available. Thus, it is of great interest to study the in vivo cardiac contractile and electrical changes in response to chronic metabolic acidosis.

The aim of the current study was to demonstrate the effects of chronic acidosis induced by ammonium chloride administration on the contractile and electrical activity of the heart, and to elucidate the possible underlying mechanism(s) of such effects.

\section{Materials and Methods}

\section{Experimental protocol}

Animals

Animals used were 24 adult Wistar rats, of both sexes, initially weighing 150-180 g, purchased from Vacsera animal house (Helwan), Cairo, Egypt, and housed in animal cages (4 rats/cage) with suitable ventilation, temperature of $22-25^{\circ} \mathrm{C}, 12 \mathrm{~h}$ light dark cycle and free access to food and water ad libitum in the Animal House, Department of Physiology, Faculty of Medicine, Ain-Shams University.
The current study was approved by the Ethics Committee of Faculty of Medicine, Ain Shams University.

Animals were randomly divided into:

GROUP I: control group (C) $(n=12)$. Rats of this group received rodent chow and tap water ad libitum.

GROUP II: chronic metabolic acidosis group (initial $n=14$, two rats died during the experiment). They received orally $0.28 \mathrm{M} \mathrm{NH}_{4} \mathrm{Cl}$ in the drinking tap water for 2 weeks (Kwon et al. 2002) ad libitum with rodent chow similar to that of control group. The daily acid load administered was $11 \pm 1 \mathrm{mmol} /$ day/rat.

Throughout the experimental period, the daily water intake for each cage was measured by specific water bottle for 3 rats in the cage in both groups. No differences in either water consumption or food intake were found between the groups all through the two weeks.

At the end of experimental period, all rats were subjected to arterial blood pressure measurement using non-invasive small animal tail blood pressure system (NIBP200A, Biopac systems Inc, USA).

On the day of sacrifice, overnight fasted rats were anesthetized with intraperitoneal injection of pentobarbitone $(40 \mathrm{mg} / \mathrm{kg} \mathrm{b} . w$.$) Transthoracic$ echocardiography was performed; then, rats were subjected to ECG recording, using the ECG recorder Cardimax FX-2111 (Fukuda Denshi Co., Ltd., Japan). All leads were established by subcutaneous needle electrodes. From lead II of ECG tracing, the heart rate, the voltages of $\mathrm{R}$ and $\mathrm{T}$ waves as well as the QRS and $\mathrm{T}$ wave duration and the durations of P-R and Q-T intervals were calculated in seconds. Corrected QT interval (QT-c) was calculated according to Goldschlager and Goldman (1984):

$$
\text { QT-c interval }=\mathrm{Q}-\mathrm{T} \text { interval } / \sqrt{ }(\mathrm{R}-\mathrm{R} \text { interval })
$$

Transthoracic echocardiographic evaluation was performed using Vivid 7 Dimension, GE (Vingmed ultrasound AS N-3190 Horten, Norway), left ventricular (LV) systolic function was determined by estimation of ejection fraction and shortening fraction (Cloez et al. 1988) (Courtesy of the Pediatric Department, Faculty of Medicine, Ain Shams University). The left hemi-thorax was carefully shaved and a prewarmed ultrasound transmission gel (Parker Laboratory, Orange, NJ) was applied to the precordium.

Ejection fraction was calculated from the left ventricle (LV) cross-sectional area (2-D short-axis view) 
using the equation:

Ejection fraction $(\%)=[($ LVDA-LVSA $) /$ LVDA $] \times 100$

Fraction of shortening, a measure of LV systolic function, was calculated from the M-mode LV dimensions using the following equation:

\section{Fraction of shortening $(\%)=[($ LVEDD - LVESD $) / L V E D D] \times 100$}

Then an abdominal midline incision was performed, blood samples from the abdominal aorta were collected into two tubes, EDTA containing tube for complete blood count, the other tube was heparinized, and thereafter, centrifuged at $4000 \mathrm{rpm}$ for $15 \mathrm{~min}$, then the separated plasma was used for subsequent determination of $\mathrm{pH}$ and plasma levels of sodium bicarbonate, chloride, sodium, potassium, aldosterone, troponin I, creatine kinase (CK-MB), interleukin 6 (IL-6).

Also, cardiac tissue samples from both groups were dissected and preserved at $-80{ }^{\circ} \mathrm{C}$ for subsequent determination of cardiac tissue aldosterone and IL-6. Also, hearts from both groups were subjected to histopathological examination.

Red blood cells parameters were performed by the use of Coulter T-660, according to the method described by Coulter (1956), depending upon electronic counting to study erythrocyte count (millions/ $\mu \mathrm{l}$ ), hemoglobin level $(\mathrm{gm} / \mathrm{dl})$, and hematocrite value (\%).

Blood $\mathrm{pH}$ and sodium bicarbonate were measured using gas analyzer BEARS supplied by CIBA corning Diagnostics Corp. (Medfield, MA, USA).

Determination of plasma levels of chloride, sodium, potassium, renin, CK-MB, troponin I, IL-6 and aldosterone, and cardiac tissue levels of IL-6 and aldosterone were performed using commercially available kits.

For histological examination of heart the samples were fixed in $10 \%$ formalin for light microscopy. Paraffin embedded sections of $5-\mu \mathrm{m}$ thickness were stained with hematoxylin and eosin and Mallory stain for subsequent microscopic examination under high power (Bancroft and Gamble 2002). Also, the hearts of both groups were studied by immunohistochemistry by using antibodies against caspase III.

\section{Statistical analysis}

All results in the present study were expressed as mean \pm SEM. Statistical Package for the Social Sciences
(SPSS, Inc., Chicago, IL, USA) program, version 20.0 was used to compare significance between the two groups. Comparisons were made using unpaired t-test. Differences were considered significant when $\mathrm{P} \leq 0.05$.

\section{Results}

As regards ECG changes (Table 1), chronic metabolic acidosis (MA) group showed significant bradycardia compared to control (C) group (297.27 \pm 14.39 vs. $369.3 \pm 17.07, \mathrm{P}<0.005)$. Also, $\mathrm{T}$ wave duration was significantly prolonged $(85.46 \pm 2.82$ vs. $58 \pm 4.67, \mathrm{P}<0.001$ ), and of significantly higher voltage $(300 \pm 30.15$ vs. $215 \pm 15, \quad \mathrm{P}<0.05)$, in addition to significant prolongation of QTc interval (255.27 \pm 7.43 vs. $221.5 \pm 9.26, \mathrm{P}<0.02)$. However, insignificant changes in QRS duration, R voltage and PR interval between the two groups were observed. Also, elevated ST segment was prominent in some rats of chronic MA group.

Regarding echocardiographic parameters of left ventricular systolic function (Table 1), chronic MA group showed significant reduction in ejection fraction and in fraction of shortening compared to $\mathrm{C}$ group $(55.14 \pm 2.14 \%$ vs. $70 \pm 3.8 \%, \mathrm{P}<0.01$ and $29 \pm 3 \%$ vs. $40 \pm 3.16 \%, \mathrm{P}<0.05$, respectively), systolic and diastolic blood pressure values were significantly decreased in chronic MA group compared to $\mathrm{C}$ group (94.1 \pm 1.23 vs. $126.8 \pm 1.32,68 \pm 0.76$ vs. $85.8 \pm 0.8, \mathrm{P}<0.001$ for each).

Plasma levels of troponin I, CK-MB and IL-6 were significantly elevated in the chronic MA group compared to C group $(8.77 \pm 0.28$ vs. $0.99 \pm 0.08$, $30.85 \pm 6.65$ vs. $7.05 \pm 0.81,127.67 \pm 20.57$ vs. $61.38 \pm 1.26$, $\mathrm{P}<0.001, \quad \mathrm{P}<0.005, \quad \mathrm{P}<0.01$, respectively) (Table 2). Similarly, cardiac tissue IL-6 was significantly increased in chronic MA group compared to $\mathrm{C}$ group (62.29 \pm 1.45 vs. $45.41 \pm 1.15, \mathrm{P}<0.001)$. As shown in Table 2 , rats received $\mathrm{NH}_{4} \mathrm{Cl}$ for 2 weeks showed significant decrease in both plasma $\mathrm{pH}$ and plasma bicarbonate level compared to the $\mathrm{C}$ rats $(7.19 \pm 0.004$ vs. $7.4 \pm 0.003$, $\mathrm{P}<0.001 ; \quad 16.36 \pm 0.25 \quad$ vs. $25.81 \pm 0.3, \quad \mathrm{P}<0.001$, respectively), and significantly elevated plasma chloride level (106.22 \pm 3.26 vs. $94.47 \pm 2.94, \mathrm{P}<0.02)$. Thus, this group showed chronic hyperchloremic MA (non-anion gap MA). Chronic MA group was found to consume almost equal daily water intake compared to $\mathrm{C}$ rats, as the daily water intake for each cage was measured by specific water bottle for 3 rats in the cage in both groups. No differences in water consumption were found between the groups all through the two weeks. 
Table 1. ECG parameters, echocardiographic parameters of left ventricle systolic function and systolic and diastolic blood pressure $(\mathrm{mm} \mathrm{Hg})$ in the different studied groups.

\begin{tabular}{|c|c|c|}
\hline & $\begin{array}{c}\text { Controls } \\
(n=12)\end{array}$ & $\begin{array}{l}\text { Chronic metabolic acidosis } \\
\qquad(\mathrm{n}=12)\end{array}$ \\
\hline Heart rate (bpm) & $369.30 \pm 17.07$ & $297.27 \pm 14.39 * *$ \\
\hline$P R$ interval $(\mathrm{ms})$ & $44.00 \pm 4.00$ & $50.91 \pm 4.95$ \\
\hline QRS duration (ms) & $30.00 \pm 3.33$ & $27.28 \pm 3.04$ \\
\hline$R$ voltage $(\mu V)$ & $600.00 \pm 53.75$ & $572.73 \pm 44.91$ \\
\hline T duration (ms) & $58.00 \pm 4.67$ & $85.46 \pm 2.82 * * *$ \\
\hline T wave voltage $(\mu V)$ & $215 \pm 15.00$ & $300 \pm 30.15^{*}$ \\
\hline$Q T-c$ interval $(m s)$ & $221.50 \pm 9.26$ & $255.27 \pm 7.43 *$ \\
\hline Ejection fraction (\%) & $70 \pm 3.80$ & $55 \pm 2.14 * *$ \\
\hline Fraction of shortening (\%) & $40 \pm 3.16$ & $29 \pm 3.00 *$ \\
\hline Systolic blood pressure (mm Hg) & $126.8 \pm 1.32$ & $94.1 \pm 1.23 * * *$ \\
\hline Diastolic blood pressure (mm Hg) & $85.8 \pm 0.80$ & $68.0 \pm 0.76^{* * *}$ \\
\hline
\end{tabular}

Significance from control group by LSD: * $\mathrm{P}<0.05$, ** $\mathrm{P}<0.01, * * * \mathrm{P}<0.001$.

Table 2. Biochemical changes in plasma and cardiac tissue in the different studied groups.

\begin{tabular}{|c|c|c|}
\hline & $\begin{array}{c}\text { Controls } \\
(n=12)\end{array}$ & $\begin{array}{l}\text { Chronic metabolic acidosis } \\
\qquad(\mathrm{n}=12)\end{array}$ \\
\hline Troponin I (ng/ml) & $0.99 \pm 0.08$ & $8.77 \pm 0.28 * * *$ \\
\hline Creatine kinase (CK-MB) (U/l) & $7.05 \pm 0.81$ & $30.85 \pm 6.65^{* *}$ \\
\hline Plasma IL-6 (pg /ml) & $61.38 \pm 1.26$ & $127.67 \pm 20.57 * *$ \\
\hline Cardiac tissue IL-6 (pg /ml) & $45.41 \pm 1.15$ & $62.29 \pm 1.45^{* * *}$ \\
\hline Blood pH & $7.40 \pm 0.003$ & $7.19 \pm 0.004 * * *$ \\
\hline Plasma bicarbonate (m M) & $25.81 \pm 0.30$ & $16.36 \pm 0.25 * * *$ \\
\hline Plasma chloride (mEq/l) & $94.47 \pm 2.94$ & $106.22 \pm 3.26^{*}$ \\
\hline Plasma $\mathrm{Na}^{+}(m E q / l)$ & $138.42 \pm 19.30$ & $213.41 \pm 17.60^{*}$ \\
\hline Plasma $K^{+}(m E q / l)$ & $5.28 \pm 0.25$ & $3.73 \pm 0.36^{* *}$ \\
\hline Plasma renin $(\mathrm{pg} / \mathrm{ml})$ & $17.65 \pm 1.01$ & $37.80 \pm 1.07 * * *$ \\
\hline Plasma aldosterone (ng/ml) & $25.14 \pm 3.47$ & $62.60 \pm 7.14 * * *$ \\
\hline Cardiac tissue aldosterone $(\mathrm{ng} / \mathrm{ml})$ & $23.03 \pm 1.49$ & $40.04 \pm 1.88 * * *$ \\
\hline
\end{tabular}

Significance from control group by LSD: $* \mathrm{P}<0.05, * * \mathrm{P}<0.01$, *** $\mathrm{P}<0.001$.

Table 3. Changes in the red blood count (RBC), hemoglobin content $(\mathrm{Hb})$ and hematocrit value $(\mathrm{Hct})$ in the different studied groups.

\begin{tabular}{lcc}
\hline & $\begin{array}{c}\text { Controls } \\
(\mathbf{n}=\mathbf{1 2})\end{array}$ & $\begin{array}{c}\text { Chronic metabolic } \\
\text { acidosis } \\
(\mathbf{n}=\mathbf{1 2})\end{array}$ \\
\hline$R B C\left(10^{6} / \mu l\right)$ & $6.73 \pm 0.20$ & $5.62 \pm 0.70^{* *}$ \\
$H b(g / d l)$ & $13.00 \pm 0.36$ & $11.74 \pm 0.22^{* *}$ \\
$H c t(\%)$ & $32.07 \pm 1.16$ & $30.64 \pm 0.49^{* *}$ \\
\hline
\end{tabular}

Significance from control group by LSD: $* * P<0.01$.
Chronic MA group showed significant increase in plasma sodium level $(213.41 \pm 17.6$ vs. $138.42 \pm 19.3$, $\mathrm{P}<0.05)$, significant decline in potassium level $(3.73 \pm 0.36$ vs. $5.28 \pm 0.25, \mathrm{P}<0.01)$, and significant rise in plasma renin and aldosterone $(37.8 \pm 1.07$ vs. $17.65 \pm 1.01$, $\mathrm{P}<0.001 ; \quad 62.6 \pm 7.14 \quad$ vs. $\quad 25.14 \pm 3.47, \quad \mathrm{P}<0.001$, respectively). Also, there was significant rise in cardiac tissue aldosterone level in chronic MA group compared to $\mathrm{C}$ group (40.04 \pm 1.88 vs. $23.03 \pm 1.49, \mathrm{P}<0.001)$.

As regards red blood cell parameters, erythrocyte count (RBC) $\quad(5.62 \pm 0.7$ vs. $6.73 \pm 0.2$, $\mathrm{P}<0.005)$, hemoglobin level (Hb) $(11.74 \pm 0.22$ vs. 
$13 \pm 0.36, \mathrm{P}<0.01)$ and hematocrit value (Hct) $(30.64 \pm 0.49$ vs. $32.07 \pm 1.16, \mathrm{P}<0.005)$ were all significantly lowered in chronic MA group compared to $\mathrm{C}$ group, as shown in Table 3 .

\section{Histology}

As shown in Figures 1a, $1 \mathrm{~b}$ and 1c, the wall of the apical region of the left ventricle of the $\mathrm{C}$ group revealed regularly arranged cardiac muscle fibers, appearing branching, anastomosing and running in various directions. The myocardial cells were attached end to end. The nuclei appeared central and vesicular, and the sarcoplasm appeared acidophilic and striated. In transverse section, the cardiac myocytes appeared more or less comparable in size with noticeable myofibrillar content.

The cardiac muscle specimens of chronic MA rats exhibited congestion of blood vessels with apparent affection of cardiac myocytes (Fig. 2a), in the form of mononuclear cellular infiltration of the cardiac muscle. Also, distortion of some cardiac myocytes, together with some areas of complete degeneration and fragmentation of the cells was observed (Fig. 2b). Loss of the regular arrangement of the cardiac myocytes was observed in (Figs $2 \mathrm{c}$ and 2d), together with marked cell vacuolation (Fig. 2d) in addition to leukocytic infiltration (Fig. 2e).
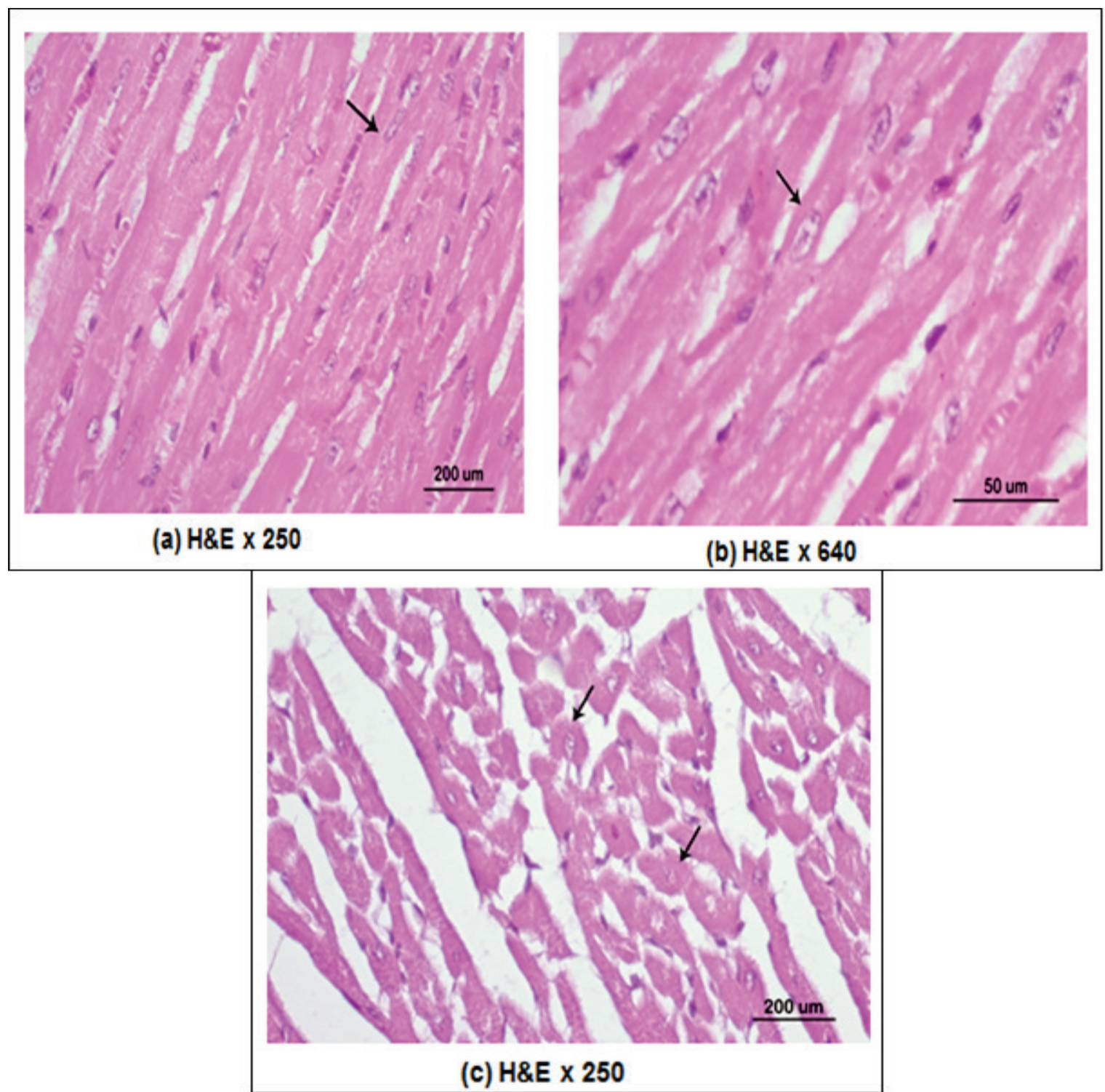

Fig. 1. Photomicrographs of control heart $(\mathbf{a}, \mathbf{b})$ longitudinal section showing regularly arranged cardiac muscle fibres branching, anastomosing and attached end to end (black arrow in a), with central and vesicular nuclei (black arrow in b), and acidophilic sarcoplasm. (c) Transverse section in control heart showing normal sized cardiac myocytes (black arrow). 


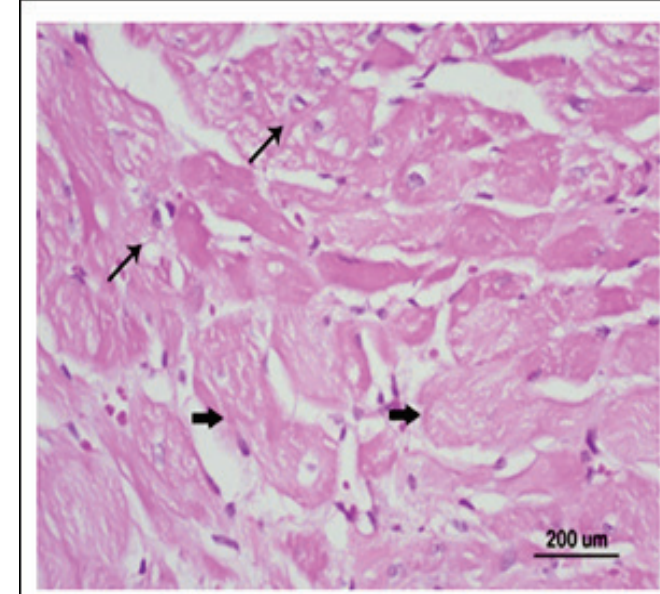

(a) H\&E $\times 250$

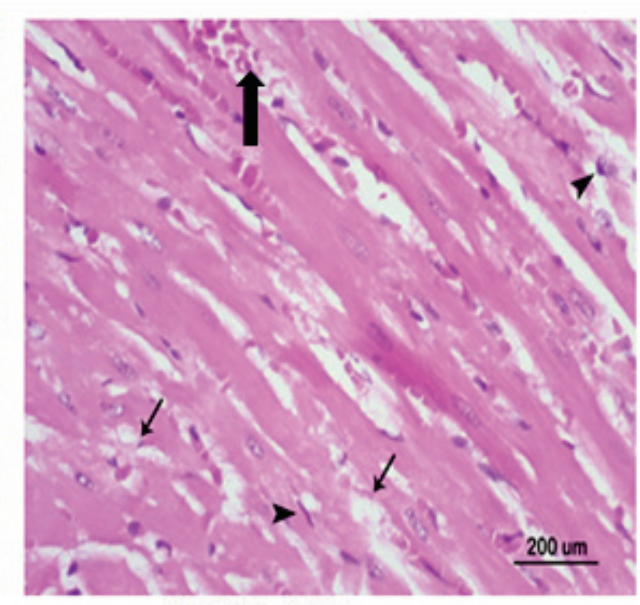

(b) H\&E $\times 250$

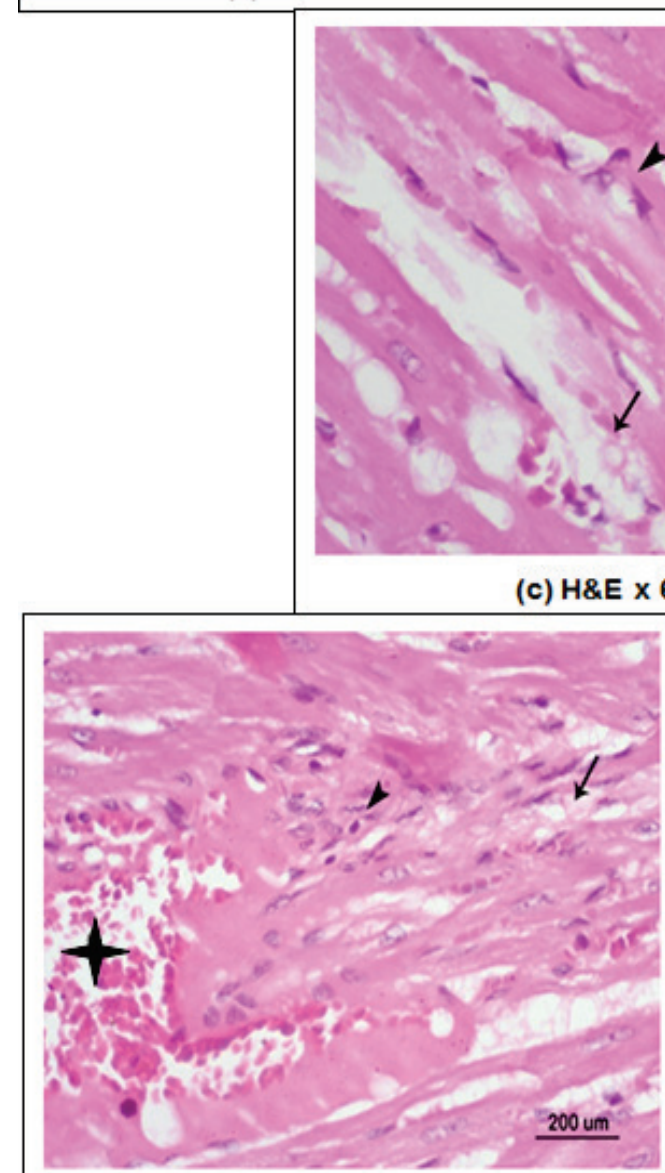

(d) H\&E $\times 250$

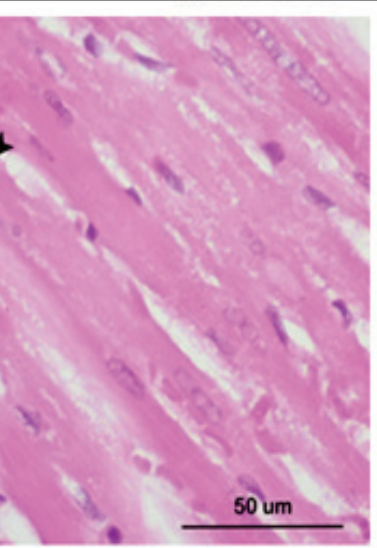

\section{0}

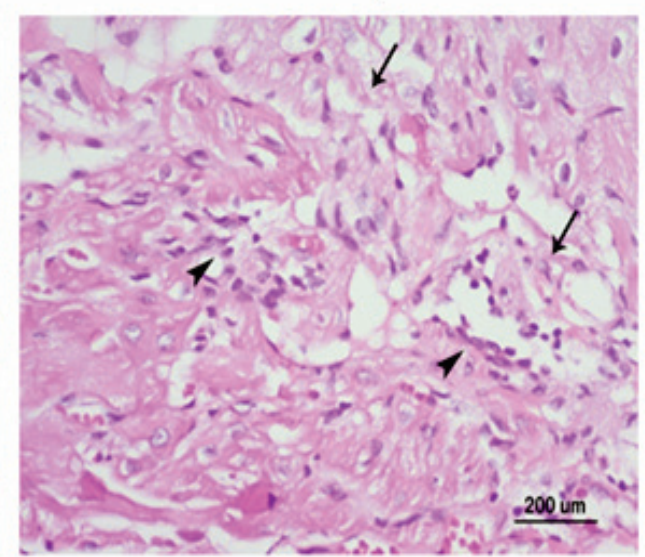

(e) H\&E X 250

Fig. 2. Photomicrographs of heart of chronic metabolic acidosis group showing acidophilic sarcoplasm and vesicular nuclei (black heads in $\mathbf{a}$ and $\mathbf{b}$ ). Areas of complete degeneration and fragmentation of cardiac myocytes (arrow in $\mathbf{c}$ ), with observed loss of the regular arrangement of the cardiac myocytes together with marked cell vacuolation (arrow in d), congested blood vessels (+ in d), and mononuclear cellular infiltration of the cardiac muscle (arrow in e).

There was less or minimal fibrous tissue around the blood vessels in the $\mathrm{C}$ group as stained by Mallory (Fig. 3a), while the heart of chronic MA group showed dense fibrous tissue distorting the normal arrangement of cardiac myocytes (Fig. 3b).
Immunohistochemistry study, by using antibodies against caspases, revealed that the heart of chronic MA group showed large areas of positive reaction compared to the heart of $\mathrm{C}$ group which caused minimal areas with positive reaction (Figs 3c and $3 d$ ). 


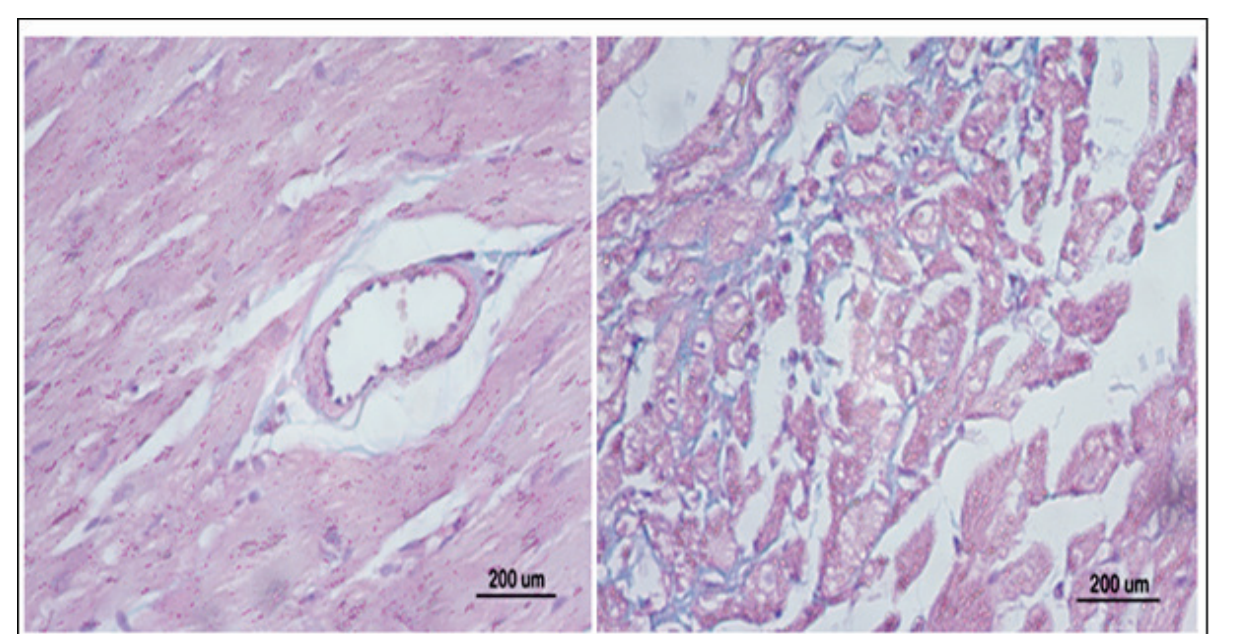

(a) Masson $\times 250$

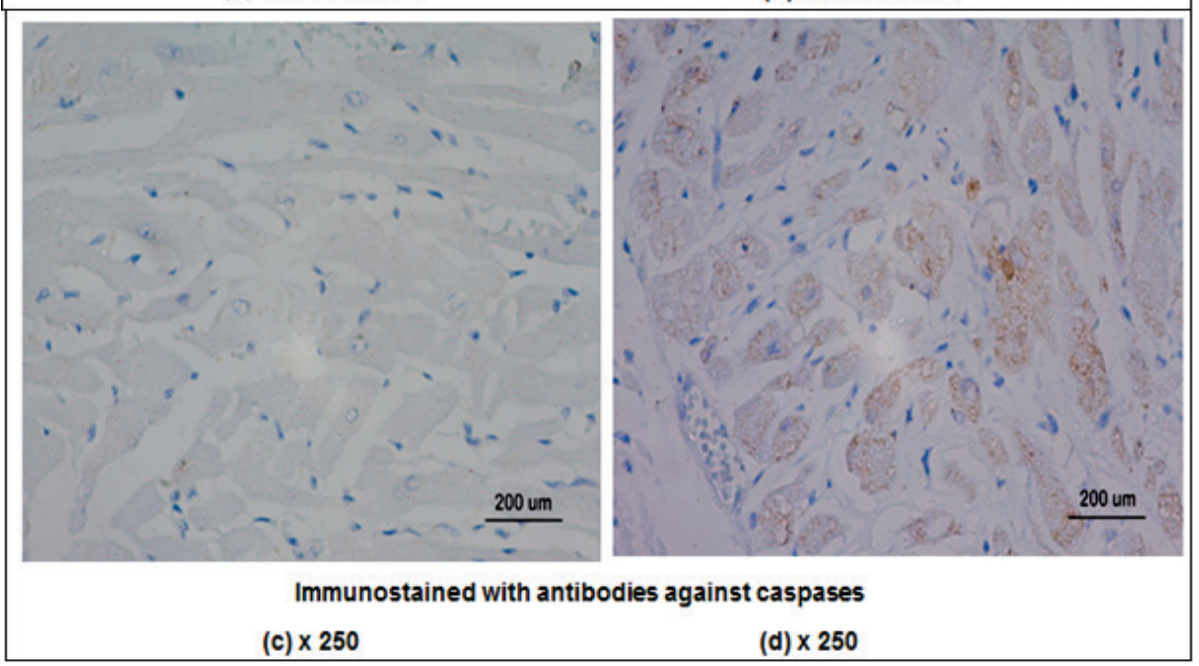

Fig. 3. (a) Photomicrograph of control group heart stained with Masson showing minimal fibrous tissues. (b) Photomicrograph of chronic metabolic acidosis group heart stained with Masson showing dense fibrous tissues distorting cardiac myocytes appeared in blue color. (c) Photomicrograph of control heart immunostained with antibodies against caspase showing no areas with positive reaction. (d) Photomicrograph of chronic metabolic acidosis group immunestained with antibodies against caspase showing large areas with positive reaction.

\section{Discussion}

Rats received $\mathrm{NH}_{4} \mathrm{Cl}$ in drinking water developed hyperchloremic (non-anion gap) metabolic acidosis (MA), confirmed by a blood $\mathrm{pH}$ of 7.19, less bicarbonate and higher chloride levels in plasma. The death rate was $14 \%$ in rats received $\mathrm{NH}_{4} \mathrm{Cl}$. During the two weeks period, the renal compensation to restore acid base balance were present but ineffective proved by decrease in alkali reserve found in chronic MA group at the end of experimental period. Chronic metabolic acidosis could raise urinary net acid excretion, together with adaptive renal tubular changes to increase urinary acidification such as rise in both $\mathrm{Na}^{+} / \mathrm{H}^{+}$exchanger activity (Alpern 1990), and increased bicarbonate reabsorption capacity in proximal tubules and the medullary collecting ducts, and enhanced $\mathrm{NH}_{4}{ }^{+}$secretion in the proximal tubule (Good and Knepper 1985). The elevated plasma chloride level could be also caused by chloride load (present in food plus the added $\mathrm{NH}_{4} \mathrm{Cl}$ to drinking water).
Chronic MA group showed significant bradycardia compared to $\mathrm{C}$ group. Similar results were obtained by Satoh and Hashimoto (1983) and Satoh and Seyama (1986), who found a negative chronotropic effect of acidosis in canine and rabbit SA nodal tissues respectively. The acidosis induced bradycardia could be explained by a direct inhibitory effect of acidosis on the SA node (Maruna 1958).

The electrocardiographic changes observed in the present study, could be attributed to ventricular action potential duration changes. In acidosis, varied action potential duration and configurational changes were noticed such as small depolarization of the resting potential caused by regional differences in channel expression (Orchard and Cingolani 1994). Acidosis, present in ischemia, caused a marked depression of the sub-epicardial action potential, and altered repolarization pattern resulting in arrhythmias (Antzelevitch et al. 1991, Crampin et al. 2006), manifested in the present study as elevated ST segment in chronic MA group. Also, the lowered plasma potassium level, observed in the current 
study, could explain widened $\mathrm{T}$ wave.

However, prolonged QTc interval and widened $\mathrm{T}$ wave observed in the current study disagree with the study of Stengl et al. (2013), who found no effect of acidosis on the action potential. This could be due to presence of a complex humoral and nervous regulation present in vivo and/or to inherent limitations in the QT-interval correction.

The insignificant change in QRS duration in chronic MA group, despite significant bradycardia, is similar to Aberra et al. (2001), who reported that acidosis slowed cardiac pacemaker activity without affecting time course of the action potential spread through the ventricles.

The different models, in vivo and in vitro, used in studying cardiac functions in acidosis should be considered because the isolated heart was not working against a load, and was not stretched in addition to plasma potassium changes and chemoreceptor mediated reflexes could alter the ECG in vivo (Aberra et al. 2001).

Chronic MA caused left ventricular systolic dysfunction detected by transthoracic echocardiographic heart examination, which is an excellent non-invasive tool to assess left ventricular structure and function (Picard et al. 1990); however, it is limited by the small sized rat animal and rapid heart rate (Litwin et al. 1994). The negative inotropic effect of acidosis, in the present study, agrees with many previous studies (Paulsen et al. 2006, Stengl et al. 2013). Paulsen et al. (2006) reported that diabetic ketoacidosis caused impaired left ventricular function and developed myocardial necrosis that could be due to increased caspase concentration in the heart, which was evident in the current study by immunostaining with caspases antibodies. Stengl et al. (2013) found reduced cardiac contractile function in MA despite maintained cardiac output caused by adaptive sympathetic changes. Biais et al. (2012) reported that acidosis could impair the positive inotropic effect of $\beta$-adrenergic stimulation, and could affect cardiac muscle lusitropy, which could be due to cardiac tissue fibrosis observed histologically, also in the current study. In addition, acidosis could decrease calcium sensitivity of troponin I (Orchard 1987), a target protein of protein kinase A-dependent phosphorylation during $\beta$-receptor stimulation (Biais et al. 2012).

In addition, $\mathrm{Na}^{+} / \mathrm{H}^{+}$exchange (NHE), the primary process by which the cardiac cell extrudes protons especially in intracellular acidosis, is expressed in all tissues. Cardiac cells have primarily the ubiquitous NHE-1 subtype which could contribute to chronic maladaptive myocardial responses to injury with development of heart failure (Karmazyn et al. 2008). NHE could be activated by autocrine, paracrine and hormonal factors such as endothelin-1, angiotensin II, and $\alpha 1$ adrenoceptor agonists via phosphorylation-dependent processes (Fliegel and Karmazyn 2004). Thus, the elevated hydrogen protons in extracellular fluid could cause systolic dysfunction (Biais et al. 2012), by reducing $\mathrm{Na}^{+}-\mathrm{K}^{+}$-ATPase activity in myocardial cells (Brown et al. 1978), producing heart failure (Mitchell et al. 1972).

In the present study, the significantly elevated aldosterone in both plasma and cardiac tissue in chronic MA group could be one of the underlying mechanisms of depressed cardiac contractile function in acidosis. Aldosterone induced cardiac fibrosis evidenced histologically, is in agreement with Brilla et al. (1990), who found that aldosterone rise could affect regulation of collagen synthesis within the cardiac interstitium and in the adventitia of intramyocardial coronary arteries.

In addition, significant hypotension in chronic MA group is similar to Kopple et al. (2005) who found hypotension in chronic MA, in chronic kidney diseases patients. The observed hypotension could be attributed to chronic MA-induced depressed myocardial contractility, noticed by echocardiography and ECG, as well as, histological cardiac changes in the form of degeneration and fibrosis. Kraut and Madias (2012) reported that acidosis caused depressed cardiac contractility, increased susceptibility to cardiac arrhythmias and hypotension.

The acidosis-induced hypotension, in the present study, is the stimulating factor for the significant rise of plasma aldosterone level and plasma renin activity observed in this study according to Vendeloo et al. (2011). They reported that less sodium reabsorption, in the proximal tubules, could occur early in metabolic acidosis due to lowered glomerular filtrated bicarbonate amount, thus, the distally increased sodium could cause a hyperreninemic hyperaldosteronism state. Similarly, Györke et al. (1991) suggested that aldosterone rise in MA could be mediated by the combined effect of sodium and water diuresis-related increased plasma renin activity, early hyperkalemia and direct stimulation of adrenal steroidogenesis. Also, Schambelan et al. (1987) suggested that chronic $\mathrm{NH}_{4} \mathrm{Cl}$-induced acidosis could cause a sustained stimulation of aldosterone secretion without ACTH secretion change. They mentioned that other factors than increased renin secretion and raised plasma potassium concentration might be involved in, at least the early phase of aldosterone stimulation, 
suggesting that plasma hydrogen ion concentration might be a separate regulator of aldosterone secretion.

The acidosis-induced myocardial damage, manifested by elevated plasma levels of CK-MB and troponin I in chronic MA group, agrees with $\mathrm{Wu}$ et al. (2013).

However, the elevated plasma levels of cardiac enzymes, the hypotension and the bradycardia observed in chronic MA group disagree with George et al. (1996), who observed unaltered heart rate, cardiac enzymes and arterial pressure in diabetic ketoacidosis. They suggested that short-term ketoacidosis did not contribute to the abnormalities of ventricular function in diabetes mellitus. Thus, the deteriorated cardiac functions, observed in the current study, could be due to longer duration of MA.

Chronic MA caused disruption of myocytes arrangement, fibrosis together with apoptosis, which might be caused by high plasma and cardiac aldosterone levels, thereby affecting left ventricular systolic function and electrical activity with subsequent elevation of plasma troponin I and CK-MB.

The renal handling of sodium could be dependent on the time course of acidosis. Within the first $24 \mathrm{~h}$ after acidosis induction, decreased salt and water reabsorption in the proximal tubule with subsequent natriuresis (Wiederkehr and Krapf 2001, Faroqui et al. 2006), could be correlated with a reduced bicarbonate level in the peritubular capillaries (Hebert et al. 1972). Therefore, natriuresis caused extracellular volume decrease, resulting in a secondary hyperaldosteronism (Wiederkehr and Krapf 2001). However, in prolonged chronic MA, there was progressive rise of sodium reabsorption, together with a progressive increase in $\mathrm{Na}^{+} / \mathrm{H}^{+}$exchanger 3 isoform protein abundance in the apical membranes along the proximal tubule and thick ascending limb (Ambühl et al. 1996). Faroqui et al. (2006) found that after 5 days of chronic MA, there were aldosterone-induced upregulation of serum- and glucocorticoid-regulated kinase, epithelial $\mathrm{Na}^{+}$channel, $\mathrm{Na}^{+} / \mathrm{Cl}^{-}$cotransporter leading to lowered urinary sodium excretion rate. Therefore, Amlal et al. (2004) reported that enhanced sodium reabsorption in the distal tubule could be a compensatory response to impaired proximal tubular function.

Therefore, the observed hyperaldosteronism in chronic MA group could have deleterious cardiovascular effects. Stowasser et al. (2005) reported that increased aldosterone level could induce cardiac and vascular damage in young humans, before the onset of hypertension. Moreover, mineralocorticoids receptor signaling could be directly involved in macrophagedependent cardiac remodeling and fibrosis (Usher et al. 2010), which could explain the fibrosis observed by Mallory stain which could be caused by increased cardiac tissue IL-6.

Further, the elevated plasma aldosterone level caused lowered plasma $\mathrm{K}^{+}$level in chronic MA group, which disagrees with Afzal et al. (2013), who found moderate to severe hyperkalemia in high anion gap MA. Acute hyperkalemia could be present in MA, and could be caused by extracellular potassium shift (Schales and Schales 1941). However, Menegon et al. (1998) reported that chronic MA in rats might increase urinary $\mathrm{K}^{+}$ excretion. In acidosis, there could be other factors indirectly affecting potassium level such as aldosterone, impaired renal function, volume depletion, and diarrhea (Hamm et al. 2013). Thus, the significantly lowered plasma $\mathrm{K}^{+}$level present in this study could be due to overriding of elevated plasma aldosterone on the potassium shift, as the hyperreninemic hyperaldosteronism could stimulate distal sodium reabsorption, causing potassium wasting. The persistent higher plasma aldosterone level, despite lowered plasma potassium level in the present study, is in accordance to Magner et al. (1988). They observed a prompt plasma potassium rise in acute MA, and after 3 to 5 days of acidosis, hypokalemia was developed due to increased urinary $\mathrm{K}^{+}$excretion mediated by renal aldosterone action.

Local synthesis of Ang I and II could be present in the heart muscle (Danser and Schalekamp 1996). Aldosterone, produced in the heart like Ang II, could be attributed not only to ACE but also to a serin protease named heart chymase (CMA) (Gumprecht et al. 2002). Thus, the elevated plasma and cardiac tissue aldosterone levels in the current study could be suggested as underlying mechanism(s) of cardiac fibrosis and left ventricular systolic dysfunction. Funder (1997) reported that mineralocorticoid receptor and $11 \mathrm{~b}$-hydroxysteroid dehydrogenase, which increases mineralocorticoid selectivity to aldosterone target tissues, could be present in heart. Also, aldosterone could have stimulatory effect on cardiac collagen synthesis, thereby producing cardiac fibrosis (Brilla et al. 1990, Robert et al. 1994); however, its mechanism was unclear (Robert et al. 1995). In addition, aldosterone was reported to cause baroreceptor dysfunction (Wang 1994) and preventing myocardial uptake of norepinephrine (Struthers 1996). Also, the 
potassium changes in MA could affect cardiovascular function (Terkildsen et al. 2007).

The significantly elevated IL-6 observed in chronic MA group is in accordance to Zampieri et al. (2014), who reported that MA was positively associated with tumor necrosis factor (TNF- $\alpha$ ), IL-6, IL-8, and IL-10. Also, lower bicarbonate level was associated with higher inflammatory biomarkers (Farwell and Taylor 2010). Kalantar-Zadeh et al. (2004) and Kellum et al. (2004) mentioned that severe MA could stimulate an acidosis inflammatory state and macrophage interleukins production. Plasma IL-6 level only gives a systemic IL-6 rise and it could be a response to acidosis by liver, adipose tissue and macrophages. Therefore, cardiac tissue IL-6 was evaluated in this study, and it was found to be significantly increased in chronic MA group, suggesting its role in cardiac tissue fibrosis induced by MA. This could be supported by the study of Mann (2002), who reported that inflammatory cytokines might modulate myocardial functions via different mechanisms including stimulation of hypertrophy and fibrosis through direct effects on cardiomyocytes and fibroblasts, manifested in the current study by dense fibrous tissues. Also, IL-6 could impair myocardial contractile function through direct effects on intracellular calcium transport and signal transduction through $\beta$-adrenergic receptors, induction of apoptosis, which was evident in the current study by positive reaction to immunostaining with anti-caspases antibodies. Thus, the left ventricular contractile dysfunction could be attributed partially to the elevated IL-6 mainly in cardiac tissue in the present study (Aukrust et al. 1999, Damås et al. 2000).

It is worth noting that the direct effect of acidosis on the previously described changes could be present; however, the rat survival for 2 -weeks period with acidosis could ensure that the daily slight $\mathrm{H}^{+}$ions addition when being uncompensated, development of metabolic acidosis could ensue. This could be supported by the study of Biais et al. (2012), who studied acute metabolic acidosis effect on papillary muscles in Wistar rats at $\mathrm{pH}=7.10$. They reported that myocardial consequences occurred below a $\mathrm{pH}$ of 7.20 which could be clinically relevant.

The acidosis-induced anemia in the present study could be due to increased RBCs hemolysis, iron deficiency or bone marrow depression. The increased hemolysis might be due to reduced $\mathrm{Na}^{+}-\mathrm{K}^{+}$-ATPase activity in RBCs (Levin et al. 1972), or by chronic MA induced inflammatory mediators (Andrews 2004), present in this study by plasma IL-6 rise. In addition, Khositseth et al. (2008) reported that acidosis could aggravate the degree of hemolytic anemia. Andrews (2004) reported that the inflammatory cytokines, such as IL-6, could induce production of hepcidin, an iron-regulatory hormone inhibiting macrophage iron release and intestinal iron absorption, leading to hypoferremia. Thus, the observed increased IL- 6 in chronic MA group could further explain the associated anemia in this group. In addition, Mann (2002) suggested that the indirect effect of inflammatory mediators in progression of heart failure through induction of systemic inflammation and impairment of bone marrow function with secondary anemia. In addition, Silverberg et al. (2004) reported that the RBCs contain many antioxidants, thereby, anemia might be associated with increased oxidative stress (Siems et al. 2000), causing myocardial cell function impairment. Therefore, the observed anemia could cause cardiac dysfunction in chronic MA.

Moreover, the chronic MA-induced anemia might cause aldosterone level rise. This might be explained by peripheral ischemia, peripheral arteriolar vasodilatation, with subsequent hypotension (detected in the present study) as a consequence of anemia, with the resultant activation of the renin-angiotensin-aldosterone system (Anand et al. 1993), which was also evident in the present study by significant rise of both plasma renin and aldosterone.

\section{Conclusion}

Chronic metabolic acidosis induced by $\mathrm{NH}_{4} \mathrm{Cl}$ had detrimental effects on cardiac function in the form of negative chronotropic and inotropic cardiac effects, hypotension, arrhythmia which could be due to fibrosis and apoptosis in addition to anemia. The acidosis-related alterations in cardiac functions could be due to elevated plasma and cardiac tissue of both aldosterone and IL-6 levels.

\section{Conflict of Interest}

There is no conflict of interest.

\section{Acknowledgements}

This study was not funded from any institute, it was only funded by the authors themselves.

\section{Abbreviations}

CK-MB - creatine kinase $\mathrm{MB}$ subform, $\mathrm{ENaC}$ - 
epithelial sodium channel, IL - interleukin, LV - left ventricle, NHE1 - $\mathrm{Na}^{+} / \mathrm{H}^{+}$exchanger, RAAS - renin- angiotensin-aldosterone system, TNF- $\alpha$ - tumor necrosis factor $\alpha$.

\section{References}

ABERRA A, KOMUKAI K, HOWARTH FC, ORCHARD CH: The effect of acidosis on the ECG of the rat heart. Exp Physiol 86: 27-31, 2001.

AFZAL B, MEHMOOD A, SHAHBAZ S, KABIR S, ZAI TK: Predictors of outcome in patients presenting with moderate to severe hyperkalemia. Emergy Med 4: 169, 2013.

ALLEN DG, ORCHARD CH: The effects of changes of $\mathrm{pH}$ on intracellular calcium transients in mammalian cardiac muscle. J Physiol 335: 555-567, 1983.

ALPERN RJ: Cell mechanisms of proximal tubule acidification. Physiol Rev 70: 79-114, 1990.

AMBÜHL PM, AMEMIYA M, DANCZKAY M, LOTSCHER M, KAISSLING B, MOE OW, PREISIG PA, ALPERN RJ: Chronic metabolic acidosis increases NHE3 protein abundance in rat kidney. Am J Physiol Renal Physiol 271: 917-925, 1996.

AMLAL H, SHERIFF S, SOLEIMANI M: Upregulation of collecting duct aquaporin-2 by metabolic acidosis: role of vasopressin. Am J Physiol Cell Physiol 286: 1019-1030, 2004.

ANAND IS, CHANDRASHEKHAR Y, FERRARI R, POOLE-WILSON PA, HARRIS PC: Pathogenesis of edema in chronic anemia: Studies of body water and sodium, renal function, haemodynamics and plasma hormones. Brit Heart J 70: 357-362, 1993.

ANDREWS NC: Anemia of inflammation: the cytokine-hepcidin link. J Clin Invest 113: 1251-1253, 2004.

ANTZELEVITCH C, SICOURI S, LIOVSKY SH, LUKA A, KRISHNAN SC, DI DIEGO JM, GINTANT GA, LIU DW: Heterogeneity within the ventricular wall. Electrophysiology and pharmacology of epicardial, endocardial and M cells. Circ Res 69: 1427-1449, 1991.

AUKRUST P, UELAND T, LIEN E, BENDTZEN K, MULLER F, ANDREASSEN AK, NORDØY I, AASS H, ESPEVIK T, SIMONSEN S, FRØLAND SS, GULLESTAD L: Cytokine network in congestive heart failure secondary to ischemic or idiopathic dilated cardiomyopathy. Am J Cardiol 83: 376-382, 1999.

BANCROFT JD, GAMBLE M: Theory and Practice of Histological Techniques. Fifth ed., London (UK), Churchill Livingstone, 2002.

BIAIS M, JOUFFROY R, CARILLION A, FELDMAN S, JOBART-MALFAIT A, RIOU B, AMOUR J: Interaction of metabolic and respiratory acidosis with $\alpha$ and $\beta$-adrenoceptor stimulation in rat myocardium. Anesthesiology 117: 1212-1222, 2012.

BRILLA CG, PICK R, TAN LB, JANICKI JS, WEBER KT: Remodeling of the rat right and left ventricles in experimental hypertension. Circ Res 67: 1355-1364, 1990.

BROWN RH JR, COHEN I, NOBLE D: The interactions of protons, calcium and potassium ions on cardiac Purkinje fibres. $J$ Physiol 282: 345-352, 1978.

CLOEZ JL, SCHMIDT KG, BIRK E, SILVERMAN NH: Determination of pulmonary to systemic blood flow ratio in children by simplified Doppler echocardiographic method. J Am Coll Cardiol 11: 825-830, 1988.

COULTER WH: High speed automatic blood cell counter and cell size analyzer. Proceeding of National Electronic Conference 12: 1034, 1956.

CRAMPIN EJ, SMITH NP: A dynamic model of excitation-contraction coupling during acidosis in cardiac ventricular myocytes. Biophysics J 90: 3074-3090, 2006.

CRAMPIN EJ, SMITH NP, LANGHAM AE, CLAYTON RH, ORCHARD CH: Acidosis in models of cardiac ventricular myocytes. Phil Trans R Soc A 364: 1171-1186, 2006.

CURLEY G, CONTRERAS MM, NICHOL AD, HIGGINS BD, LAFFEY JG: Hypercapnia and acidosis in sepsis: a double-edged sword? Anesthesiology 112: 462-472, 2010.

DAMÅS JK, EIKEN HG, ØIE E, BJERKELI V, YNDESTAD A, UELAND T, TØNNESEN T, GEIRAN O, AASS H, SIMONSEN S, CHRISTENSEN G, FRØLAND SS, ATTRAMADAL GH, GULLESTAD L, AUKRUST P: Myocardial expression of CC- and CXC-chemokines and their receptors in human end stage heart failure. Cardiovasc Res 47: 778-787, 2000. 
DANSER AHJ, SCHALEKAMP ADH: Is there an internal cardiac renin-angiotensin system? Heart 76: 28-32, 1996.

FAROQUI S, SHERIFF S, AMLAL H: Metabolic acidosis has dual effects on sodium handling by rat kidney. Am $J$ Physiol Renal Physiol 291: F322-F331, 2006.

FARWELL WR, TAYLOR EN: Serum anion gap, bicarbonate and biomarkers of inflammation in healthy individuals in a national survey. CMAJ 182: 137-141, 2010.

FLIEGEL L, KARMAZYN M: The cardiac Na-H exchanger: a key downstream mediator for the cellular hypertrophic effects of paracrine, autocrine and hormonal factors. Biochem Cell Biol 82: 626-635, 2004.

FUNDER JW: Glucocorticoid and mineralocorticoid receptors: biology and clinical relevance. Annu Rev Med 48: 231-240, 1997.

GEORGE AK, SHIH A, REGAN TJ: Effect of acute ketoacidosis on the myocardium in diabetes. Am J Med Sci 311: 61-64, 1996.

GOLDSCHLAGER N, GOLDMAN MJ: Electrocardiography: Essentials of Interpretation. Middle East Edition, ch. 3 , Lang Medical Publications, Los Anglos, California, 1984, pp 13-18.

GOOD DW, KNEPPER MA: Ammonia transport in the mammalian kidney. Am J Physiol Renal Fluid Electrolyte Physiol 248: F459-F471, 1985.

GUMPRECHT J, ZYCHMA M, GRZESZCZAK W, ŁACKA B, BURAK W, MOSUR M, KACZMARSKI J, OTULSKI I, STOKLOSA T, CZANK P: Angiotensin I-converting enzyme and chymase gene polymorphisms - relationship to left ventricular mass in type 2 diabetes patients. Med Sci Monit 8: 603-606, 2002.

GYÖRKE ZS, SULYOK E, GUIGNARD JP: Ammonium chloride metabolic acidosis and the activity of reninangiotensin-aldosterone system in children. Eur J Pediatr 150: 547-549, 1991.

HAMM LL, HERING-SMITH KS, NAKHOUL NL: Acid-base and potassium homeostasis. Semin Nephrol 33: 257-264, 2013.

HEBERT CS, MARTINEZ-MALDONADO M, EKNOYAN G, SUKI WN: Relation of bicarbonate to sodium reabsorption in dog kidney. Am J Physiol 222: 1014-1020, 1972.

HENGER A, TUTT P, RIESEN WF, HULTER HN, KRAPF R: Acid-base and endocrine effects of aldosterone and angiotensin II inhibition in metabolic acidosis in human patients. J Lab Clin Med 136: 379-389, 2000.

KALANTAR-ZADEH K, MEHROTRA R, FOUQUE D, KOPPLE JD: Metabolic acidosis and malnutritioninflammation complex syndrome in chronic renal failure. Semin Dial 17: 455-465, 2004.

KARMAZYN M, KILIĆ A, JAVADOV S: The role of NHE-1 in myocardial hypertrophy and remodelling. J Mol Cell Card 44: 647-653, 2008.

KELLUM JA, SONG M, LI J: Science review: extracellular acidosis and the immune response: clinical and physiologic implications. Crit Care 8: 331-336, 2004.

KHOSITSETH S, SIRIKANAERAT A, KHOPRASERT S, OPASTIRAKUL S, KINGWATANAKUL P, THONGNOPPAKHUN W, YENCHITSOMANUS PT: Hematological abnormalities in patients with distal renal tubular acidosis and hemoglobinopathies. Am J Hematol 83: 465-471, 2008.

KOPPLE JD, KALANTAR-ZADEH K, MEHROTRA R: Risks of chronic metabolic acidosis in patients with chronic kidney disease. Kidney Int Suppl 95: S21-S27, 2005.

KRAUT JA, KURTZ I: Metabolic acidosis of CKD: diagnosis, clinical characteristics, and treatment. Am J Kidney Dis 45: 978-993, 2005.

KRAUT JA, MADIAS NE: Treatment of acute metabolic acidosis: a pathophysiologic approach. Nat Rev Nephrol 8: 589-601, 2012.

KWON T, FULTON C, WANG W, KURTZ I, FRØKIÆR J, AALKJÆR C, NIELSEN S: Chronic metabolic acidosis upregulates rat kidney Na-HCO3 cotransporters NBCn1 and NBC3 but not NBC1. Am J Physiol Renal Physiol 282: F341-F351, 2002.

LEVIN ML, RECTOR FC JR, SELDIN DW: The effects of chronic hypokalaemia, hyponatraemia, and acid-base alterations on erythrocyte sodium transport. Clin Sci 43: 251-263, 1972.

LITWIN SE, KATZ SE, MORGAN JP, DOUGLAS PS: Serial echocardiographic assessment of left ventricular geometry and function after large myocardial infarction in the rat. Circulation 89: 345-354, 1994.

LORENZ I: D-Lactic acidosis in calves. Vet J 179: 197-203, 2009. 
MAGNER PO, ROBINSON L, HALPERIN RM, ZETTLE R, HALPERIN ML: The plasma potassium concentration in metabolic acidosis: a re-evaluation. Am J Kidney Dis 11: 220-224, 1988.

MANN DL: Inflammatory mediators and the failing heart: past, present, and the foreseeable future. Circ Res 91: 988-998, 2002.

MARUNA RFL: Determination of serum sodium by the magnesium uranyl acetate. Clin Chem Acta 2: 581-585, 1958.

MENEGON LF, FIGUEIREDO JF, GONTIJO JA: Effect of metabolic acidosis on renal tubular sodium handling in rats as determined by lithium clearance. Braz J Med Biol Res 31: 1269-1273, 1998.

MIHAILIDOU AS: Aldosterone in heart disease. Curr Hyp Rep 14: 125-129, 2012.

MITCHELL JH, WILDENTHAL K, JOHNSON RL JR: The effects of acid-base disturbances on cardiovascular and pulmonary function. Kidney Int 1: 375, 1972.

NYIRENDA MJ, TANG JI, PADFIELD PL, SECKL JR: Hyperkalaemia. BMJ 339: b4114, 2009.

ORCHARD CH: The role of the sarcoplasmic reticulum in the response of ferret and rat heart muscle to acidosis. J Physiol (Lond) 384: 431- 449, 1987.

ORCHARD CH, CINGOLANI HE: Acidosis and arrhythmias in cardiac muscle. Cardiovasc Res 28: 1312-1319, 1994.

PAULSEN SK, POULSEN SH, THUESEN L, BAK JF: Myocardial necrosis with late occurrence of ventricular tachyarrythmia secondary to diabetic ketoacidosis. Ugeskr Laeger 168: 2680-2681, 2006.

PEREZ GO, OSTER JR, KATZ FH, VAAMONDE CA: The effect of acute metabolic acidosis on plasma cortisol, renin activity and aldosterone. Horm Res 11: 12-21, 1979.

PICARD MH, WILKINS GT, RAY PA, WEYMAN AE: Natural history of left ventricular size and function after acute myocardial infarction: assessment and prediction by echocardiographic endocardial surface mapping. Circulation 82: 484-494, 1990.

ROBERT V, VAN THIEM N, CHEAV SL, MOUAS C, SWYNGHEDAUW B, DELCAYRE C: Increased cardiac types I and III collagen mRNAs in aldosterone-salt hypertension. Hypertension 24: 30-36, 1994.

ROBERT V, SILVESTRE JS, CHARLEMAGNE D, SABRI A, TROUVE P, WASSEF M, SWYNGHEDAUW B, DELCAYRE C: Biological determinants of aldosterone induced cardiac fibrosis in rats. Hypertension 26: 971-978, 1995.

SATOH H, HASHIMOTO K: Effect of $\mathrm{pH}$ on the sino-atrial node cells and atrial muscle of dog. Arch Int Pharmacodyn Ther 17: 67-78, 1983.

SATOH H, SEYAMA I: On the mechanism by which changes in extracellular $\mathrm{pH}$ affect the electrical activity of the rabbit sino-atrial node. $J$ Physiol 17: 181-191, 1986.

SCHALES O, SCHALES SS: A simple and accurate method for the determination of chloride in biological fluids. J Biol Chem 140: 879, 1941.

SCHAMBELAN M, SEBASTIAN A, KATUNA BA, ARTEAGA E: Adrenocortical hormone secretory response to chronic NH4Cl-induced metabolic acidosis. Am J Physiol 252: E454-E460, 1987.

SCHOTOLA H, SOSSALLA S, RAJAB TK, TOISCHER K, QUINTEL M, BAUER M, SCHMITTO JD: Influence of mild metabolic acidosis on cardiac contractility and isoprenaline response in isolated ovine myocardium. Artif Organs 35: 1065-1074, 2011.

SIEMS WG, SOMMERBURG O, GRUNE T: Erythrocyte free radical and energy formation. Clin Nephrol 53: S9-S17, 2000.

SILVERBERG DS, WEXLER D, BLUM M, WOLLMAN Y, SCHWARTZ D, SHEPS D, KEREN G, IAINA A: The interaction between heart failure, renal failure and anemia - the cardio-renal anemia syndrome. Blood Purif 22: 277-284, 2004.

STENGL M, LEDVINOVA L, CHVOJKA J, BENES J, JARKOVSKA D, HOLAS J, SOUKUP P, SVIGLEROVA, MATEJOVIC M: Effects of clinically relevant acute hypercapnic and metabolic acidosis on the cardiovascular system: an experimental porcine study. Crit Care 17: R303, 2013.

STOWASSER M, SHARMAN J, LEANO R, GORDON RD, WARD G, COWLEY D, MARWICK TH: Evidence for abnormal left ventricular structure and function in normotensive individuals with familial hyperaldosteronism type I. J Clin Endocrinol Metab 90: 5070-5076, 2005.

STRUTHERS AD: Aldosterone escape during angiotensin-converting enzyme inhibitor therapy in chronic heart failure. J Card Fail 2: 47-54, 1996. 
TERKILDSEN JR, CRAMPIN EJ, SMITH NP: The balance between inactivation and activation of the Na+-K+ pump underlies the triphasic accumulation of extracellular $\mathrm{K}^{+}$during myocardial ischemia. Am J Physiol Heart Circ Physiol 293: H3036-H3045, 2007.

USHER MG, DUAN SZ, IVASCHENKO CY, FRIELER RA, BERGER S, SCHÜTZ G, LUMENG CN, MORTENSEN RM: Myeloid mineralocorticoid receptor controls macrophage polarization and cardiovascular hypertrophy and remodeling in mice. J Clin Invest 120: 3350-3364, 2010.

VENDELOO M, AARNOUDSE ALHJ, VAN BOMMEL EFH: Life-threatening hypokalaemic paralysis associated with distal renal tubular acidosis. Neth J Med 69: 35-38, 2011.

WAGNER CA: Metabolic acidosis: new insights from mouse models. Curr Opin Nephrol Hypertens 16: 471-476, 2007.

WANG W: Chronic administration of aldosterone depresses baroreceptor reflex function in the dog. Hypertension 24: 571-575, 1994.

WEINER ID, HAMM LL: Molecular mechanisms of renal ammonia transport. Annu Rev Physiol 69: 317-340, 2007.

WIEDERKEHR M, KRAPF R: Metabolic and endocrine effects of metabolic acidosis in humans. Swiss Med Wkly 131: 127-132, 2001.

WU D, KRAUT JA, ABRAHAM WM: Sabiporide improves cardiovascular function, decreases the inflammatory response and reduces mortality in acute metabolic acidosis in pigs. PLoS One 8: e53932, 2013.

YANCY WS JR, OLSEN MK, DUDLEY T, WESTMAN EC: Acid-base analysis of individuals following two weight loss diets. Eur J Clin Nutr 61: 1416-1422, 2007.

ZAMPIERI F, KELLUM J, PARK M, RANZANI O, BARBEIRO H, DE SOUZA H, MONTEIRO DA CRUZ NETO L, PINHEIRO DA SILVA F: Relationship between acid-base status and inflammation in the critically ill. Crit Care 18: R154, 2014. 